\title{
NON-SUICIDAL SELF-INJURY EXPERIENCES FOR ADOLESCENTS WHO SELF-INJURED - CONTRIBUTIONS OF WINNICOTT'S PSYCHOANALYTIC THEORY
}

\author{
Luiza Cesar Riani Costa ${ }^{1}$ (D) \\ Isabela Martins Gabriel ${ }^{2}$ (D) \\ Wanderlei Abadio de Oliveira ${ }^{3}$ (1) \\ Priscilla Hortense ${ }^{1}$ \\ Olga Lopez de Dicastillo 4 (D) \\ Diene Monique Carlos ${ }^{1}$ (D)
}

\begin{abstract}
'Universidade Federal de São Carlos, Programa de Pós-graduação em Enfermagem. São Carlos, São Paulo, Brasil. ${ }^{2}$ Universidade Federal de São Carlos, Departamento de Enfermagem. São Carlos, São Paulo, Brasil. ${ }^{3}$ Pontifícia Universidade Católica de Campinas, Programa de Pós-graduação em Psicologia. Campinas, São Paulo, Brasil. ${ }^{4}$ Universidad Pública de Navarra, Departament of Health Sciences. Pamplona, Navarra, Espanha.
\end{abstract}

\begin{abstract}
Objective: to identify and analyze the elements present in non-suicidal self-injury experiences by adolescents who self-injured.

Method: a qualitative research, with data collection conducted from August to October 2019 through individual therapeutic consultations, mediated by the dialogical resource Drawing-Story with Theme Procedure. Participants were eight adolescents who reported self-injury in a school of a municipality in the countryside of São Paulo, Brazil. Thematic analysis was developed from data anchored in Winnicott's psychoanalytic theory. Results: two thematic categories were identified: "I think nobody cares about me" and "I do not see the colors I used to see before". The elements present in adolescents' experiences on non-suicidal self-injury highlighted the importance of a physical and relational environment that offers holding and is able to integrate characteristics of the adolescence process itself. The importance of a family and peer support network, as well as the need for family, school and health professionals to be involved in coping with and preventing non-suicidal self-injury stands out.

Conclusion: non-suicidal self-injury is a multiple phenomenon, closely related to the environment, which deserves attention and care in the field of child and adolescent health. The issues present in the process of becoming an adolescent emerge as essential elements for understanding and coping with non-suicidal selfinjury. Due to their multiple characteristics, coping and prevention policies should include several areas, such as health, education, and social assistance. The presence of mental health programs in schools is fundamental.
\end{abstract}

DESCRIPTORS: Adolescent. Self-Injurious behavior. Qualitative research. Psychoanalysis. School health services. 


\section{EXPERIÊNCIAS DA AUTOLESÃO NÃO SUICIDA PARA ADOLESCENTES QUE SE AUTOLESIONARAM - CONTRIBUIÇÕES DA TEORIA PSICANALÍTICA WINNICOTTIANA}

\section{RESUMO}

Objetivo: identificar e analisar os elementos presentes na experiência da autolesão não suicida por adolescentes que se autolesionaram.

Método: pesquisa qualitativa, com coleta de dados realizada no período de agosto a outubro de 2019 por meio de Consultas Terapêuticas Individuais, mediadas pelo recurso dialógico Procedimento Desenho-Estória com Tema. As participantes foram oito adolescentes que referiram autolesão em uma escola de um município do interior de São Paulo, Brasil. A análise temática foi desenvolvida a partir dos dados, ancorada na teoria psicanalítica winnicottiana.

Resultados: foram identificadas duas categorias temáticas: "acho que não tenho importância para ninguém"; e "não vejo o colorido de antes". Os elementos presentes nas experiências das adolescentes sobre a autolesão não suicida destacaram a importância de um ambiente, físico e relacional, que ofereça holding e seja capaz de integrar características do próprio processo do adolescer. Destaca-se a importância da existência de uma rede de apoio familiar e de pares, assim como a necessidade da família, escola e profissionais de saúde se implicarem no enfrentamento e prevenção da autolesão não suicida.

Conclusão: a autolesão não suicida é um fenômeno múltiplo, intimamente relacionado com o ambiente, que merece atenção e cuidado na área da saúde da criança e do adolescente. As questões presentes no processo de adolescer emergem como elementos essenciais para a compreensão e enfrentamento da autolesão não suicida. Por sua característica múltipla, as políticas de enfrentamento e prevenção devem abarcar diversas áreas, como saúde, educação e assistência social. A presença de programas de saúde mental nas escolas faz-se fundamental.

DESCRITORES: Adolescente. Comportamento autodestrutivo. Pesquisa qualitativa. Psicanálise. Serviços de saúde escolar.

\section{EXPERIENCIAS DE AUTOLESIÓN NO SUICIDA PARA ADOLESCENTES QUE SE AUTOLESIONAN: CONTRIBUCIONES DE LA TEORÍA PSICOANALÍTICA WINNICOTTIANA}

\section{RESUMEN}

Objetivo: identificar y analizar los elementos presentes en la experiencia de autolesión no suicida por parte de adolescentes que se autoinsultan.

Método: uma investigación cualitativa, con recolección de datos realizada de agosto a octubre de 2019 a través de Consultas Terapéuticas Individuales, mediadas por el procedimiento dialógico Procedimiento DibujoHistoria con Tema. Los participantes fueron ocho adolescentes que refirieron autolesiones en una escuela de una ciudad del interior de São Paulo, Brasil. El análisis temático se desarrolló a partir de los datos, anclado en la teoría psicoanalítica winnicottiana.

Resultados: se identificaron dos categorías temáticas: "creo que no soy importante para nadie"; y "no veo los colores de antes". Los elementos presentes en las vivencias de los adolescentes sobre la autolesión no suicida resaltaron la importancia de un entorno, físico y relacional, que ofrezca agarre y sea capaz de integrar características del propio proceso del adolescente. Se destaca la importancia de tener una red de apoyo familiar y de pares, así como la necesidad de que la familia, la escuela y los profesionales de la salud se involucren en el afrontamiento y la prevención de las autolesiones no suicidas.

Conclusión: la autolesión no suicida es un fenómeno múltiple, íntimamente relacionado con el medio ambiente, que merece atención y cuidado en el área de la salud infantil y adolescente. Los temas presentes en el proceso de la adolescencia surgen como elementos esenciales para comprender y afrontar la autolesión no suicida. Por sus múltiples características, las políticas de afrontamiento y prevención deben cubrir varias áreas, como la salud, la educación y la asistencia social. La presencia de programas de salud mental en las escuelas es fundamental.

DESCRIPTORES: Adolescente. Conducta autodestructiva. Investigación cualitativa. Psicoanálisis. Servicios de salud escolar. 


\section{INTRODUCTION}

In Brazil, the number of adolescents in the population is quite significant, even considering the decrease in the growth of the young population. According to the Brazilian Institute of Geography and Statistics (IBGE - Instituto Brasileiro de Geografia e Estatística), in 2016, adolescents made up a total of $51,402,821$ people, about $36.89 \%$ of the general population. ${ }^{1}$ According to the Ministry of Health, adolescence is understood as a social category, culturally constructed, with "a material basis linked to age. This facticity of age cycles presents a particular way of being in the world in its temporality, with different distances and durations."1:17 Understanding adolescence, as well as the prevention or attention given to this social category, should go beyond universalizing and crystallized conceptions, such as those proposed only by age or puberty markers, because although it is possible to make general definitions, they are singular subjects constituted according to the history of life and the historical and sociocultural moment in which they live. ${ }^{2}$

Different institutions and organizations define different age groups for adolescence. In this study, we chose to adopt the World Health Organization's definition, which considers the range from 10 to 19 years old, being the initial period between 10 and 14 years and the end between 15 and 19 years old. ${ }^{3}$ Adolescence is a period that, compared to other age groups, does not present high rates of illness. ${ }^{1}$ Nevertheless, there are major health issues that should be observed in this population. One of these issues is self-injurying behavior, or self-injury, which has been increasingly prioritized at national and international levels in recent years. ${ }^{3}$

In the literature, there is no consensus on the nomenclature to be used to define self-injurying behaviors, which makes it difficult to understand and compare data on the subject. Currently, in the fifth version of the Diagnostic and Statistical Manual of Mental Disorders - DSM-5, the term non-suicidal self-injury has been formalized. This has been the term that best defines adolescents' actions and behaviors in the context of self-inflicted violence. In this study, we chose to follow the term non-suicidal self-injury (NSSI). ${ }^{4}$ It is worth mentioning that although NSSI has no conscious intention of suicide, people with a history of self-injury make up an important risk group for suicide prevention. ${ }^{5}$

NSSI can be defined as repeated behavior of inflicting superficial, yet painful, injuries to the surface of their body. ${ }^{4: 947}$ To be considered NSSI, the intentional body damage is done with the expectation of only physical damage, which is unlikely to result in death ${ }^{4}$ It should be noted that socially accepted behaviors such as piercing and tattooing are not considered $\mathrm{NSSI}^{4}$

According to the Epidemiological Bulletin published by the Brazilian Ministry of Health, between 2011 and 2016, 23.75\% of self-injury cases were of people between 10 and 19 years old. This number corresponds to 30,075 cases in girls and 11,789 cases in boys. ${ }^{6}$ Although the uniqueness of NSSI cases should be considered, there are certain similarities between them. An integrative review study sought to identify factors associated with self-injurying behavior in life cycle, identified several risk factors for NSSI in adolescence, including impulsivity; experimentation and abuse of alcohol and other drugs; concerns about sexual orientation; low self-esteem; parenting problems; emotional negligence; social isolation; bullying; friends with a history of NSSI, characterizing the importance of grouphood in this period. ${ }^{7}$ The phenomenon may be related to mechanisms of coping with emotions; attempts at emotional regulation through the reduction or relief of suffering and reduction of tensions; difficulty identifying and verbally expressing emotions. ${ }^{7}$ Thus, it is observed that many of the risk factors of NSSI are issues present in adolescence in general, followed by difficulties in coping with stressors.

Despite the growing interest in studying NSSI and attempts to measure the prevalence of cases, it is verified that there are still gaps in scientific production related to strategies to prevent and cope with self-injury behavior among adolescents. The current literature has worked on NSSI through descriptive analysis of virtual interactions on the subject, ${ }^{8-10}$ application of scales for analysis of frequency and characteristics of self-injurying behavior, ${ }^{11}$ and integrative review of self-injurying behavior. ${ }^{7}$ 
Thus, considering (I) the importance that NSSI has taken when it comes to health promotion and disease prevention in adolescents and (II) the gaps in scientific literature on the phenomenon, especially in health and nursing, we chose to adopt adolescents' NSSI experiences as the object of study in the present study. For this approach, we rely on D. W. Winnicott's Theory of Emotional Development. ${ }^{12}$

For this author, mental health has as one of its foundations the conception that every human individual is endowed with an innate tendency towards maturation. Although innate, this trend does not happen alone, as it does not refer to a determination. ${ }^{12}$ For this tendency to be realized and health to be achieved comprehensively, the subject fundamentally depends on the presence of a facilitating environment that provides sufficiently good care and that allows carrying out integrational processes. Thus, from Winnicott's perspective, environmental conditions (considering environment everything that influences and is influenced by the subject, such as the physical environment and personal relationships) are decisive for establishing individuals' health throughout the development process. ${ }^{12}$ In this sense, this reference is coherent to this object, considering the importance of the environment to a healthy development of adolescents.

Given this scenario, it is understood that looking at NSSI experiences by adolescents who experienced this phenomenon can provide subsidies for advancing the knowledge of coping and care strategies for NSSI. Moreover, this theme is essential to contemporary health and nursing agendas, deepening the interprofessional debate about the vulnerabilities present in adolescents' lives, as well as contributing to strengthening bonds and constructing sufficiently good environments within Primary Health Care. Thus, the aim of this study was to identify and analyze the elements present in non-suicidal self-injury experiences by adolescents who self-injured.

\section{METHOD}

This is a qualitative research, understood as that destined to the study of social relationships or phenomena. ${ }^{13}$ This design allows recognizing participants' perspectives, directly involved in a given phenomenon, and what can be understood from its nuances and singularities in terms of context. ${ }^{13}$

Specifically, this study was carried out in a municipality in the countryside of São Paulo. The city in question has 221,950 inhabitants according to the 2010 census, with an estimated 249,415 inhabitants for 2018 . The population aged 10 to 19 is 33,169 people, about $15 \%$ of this total. ${ }^{14}$ The specific field was a state elementary and middle school in a district of the municipality. This location was chosen due to: (a) the existence of a university extension project there; (b) the increasing number of NSSI situations by adolescents reported to the municipal health services; (c) the absence of interventions in this field due to the extreme vulnerability of the region. Approximately 3,000 people live in the district. The adolescent population is 385 people, which is equivalent to $13 \%$ of the total district, about $47 \%$ male and $53 \%$ female. ${ }^{14}$

In this study were included students enrolled at the aforementioned school, aged between 10 and 19 years old, appointed by the school board or teachers for experiencing NSSI situations. Adolescents excluded from school for any reason were excluded. It is emphasized that the main researcher and her advisor participated in the school life through an extension project. This aspect facilitated the approach and longitudinality of adolescents' views. The school board nominated eight female adolescents who had reported situations of NSSI, which were reported by the adolescents themselves or by their families. Before the beginning of data collection, the school board made contact with students' parents to ask for consent. The researchers held a first conversation with the adolescents to invite them to participate in the study, and all the adolescents appointed by the school board accepted. 
The data collection strategy adopted used Individual Therapeutic Consultation, mediated by the dialogical resource Drawing-Story with Theme Procedure, and the theme presented was NSSI. Therapeutic consultation is a technique developed by Winnicott that consists of few meetings (one to three), which rely on using a dialogical mediator for expression and privileges the reception of emerging contents. ${ }^{15}$ Therapeutic consultation is based on a significant communication between researcher and participant, being used as a diagnosis and as a research instrument of the contents that are afflicting participants. ${ }^{15}$ It is notelike that the first author, who performed all Therapeutic Consultations, had previous training and experience with the technique.

Winnicott states that meaningful communication appears relatively easily during this type of consultation that can use games and drawings as tools. ${ }^{12}$ Considering such notes, we chose in this study to use the Drawing-Story with Theme Procedure. ${ }^{16}$ This procedure consists of asking participants to draw a drawing with a theme predetermined by the researcher. After finishing drawing, they must tell the story of their graphic production. The researcher performs the same steps as participants. At the end of this phase, they both show their drawings and tell their stories to each other. The choice of this procedure is due to its characteristic of facilitating the immersion of contents of difficult oral expression, considering that, as previously indicated, literature indicates difficulties in expressiveness and communication in cases of self-injury. ${ }^{16}$

Data collection was performed from August 22 to October 6, 2019, in a private room in the school, without the presence of other people. The schedules were arranged with the school team in order to avoid any loss to school activities. Before the beginning of the Drawing-Story with Theme Procedure, the researcher conducted a brief sociodemographic interview. The process of drawing and talking lasted between 30 and 55 minutes. The content was recorded on the voice recorder of a Samsung J4 device after participants' consent and the audios were fully transcribed later. All of the names in this article are fictitious names, chosen by the authors. Participant anonymity was safeguarded.

The data collected with eight adolescents allowed a deeper, rich in detail and complex discussion to ensure the understanding of the phenomenon of interest, allowing a dense answer to the study question. ${ }^{17}$ Each adolescent participated in two to five individual meetings, and only the first one was used for data analysis. The first meeting included a socioeconomic survey, Drawing-Story with Theme Procedure, and the free expression of the emerging contents. At the last meeting, they received feedback, closure, and referrals necessary to health services. One of the participants was already under psychological follow-up at data collection time. It was necessary to refer four participants to psychological and medical care, in addition to talking to their parents to warn of the risk of suicide identified during data collection, after their authorization.

The data were analyzed using thematic analysis. ${ }^{18}$ Thematic analysis is essentially a method for identifying and analyzing qualitative data patterns. The following steps were conducted: (I) familiarization with data through transcription of adolescents' statements, and exhaustive readings of data set were performed; (II) coding, by creating codes that identify the data semantic and conceptual reading; (III) search for themes through the significant grouping of these initial codes; (IV) review of themes to verify their representativeness; (V) definition, description, and naming of themes. The stages of coding and definition of themes are presented in Chart 1.

The research met all ethical aspects involving human beings, being approved by an Ethics Committee and authorized by the school's research setting. The data was collected only after signing an Informed Consent Form by the guardians and the adolescents.

From data analysis, two themes emerged: "I think nobody cares about me" and "I do not see the colors I used to see before". To ensure greater data validity and reliability, the following strategies 
Chart 1 - Coding and definition of themes. Prepared by the authors. City of the state of São Paulo, Brazil, 2019.

\begin{tabular}{|c|c|c|}
\hline Initial codes & Intermediate codes & Final themes \\
\hline Here at school & \multirow{6}{*}{$\begin{array}{c}\text { Here at school } \\
\text { Fragile network } \\
\text { Parental relationships } \\
\text { I feel alone }\end{array}$} & \multirow{6}{*}{ I think nobody cares about me. } \\
\hline Only with them & & \\
\hline They don't take it too seriously & & \\
\hline When my mother found out & & \\
\hline I feel like I failed as a daughter & & \\
\hline I feel alone & & \\
\hline I hate myself & & \multirow{2}{*}{$\begin{array}{l}\text { I do not see the colors } \\
\text { I used to see before }\end{array}$} \\
\hline $\begin{array}{l}\text { I do not see the colors I used to } \\
\text { see before }\end{array}$ & & \\
\hline
\end{tabular}

were performed: return of the data to the adolescents in a later meeting to verify content coherence; peer analysis, i.e., the construction of codes and themes was made by two independent researchers validated by a third party when it was necessary; use of a field diary, ensuring greater transparency of the entire research process.

\section{RESULTS}

In terms of characterization, all study participants were female, two were 12 years old, four were 13 years old, and two were 14 years old. Five were in seventh grade and three in eighth grade. Regarding religion, four participants claimed to be Catholic, two claimed to be Evangelical and two declared they had no religion. The number of people living in the same house ranged from three to six, all of which lived with their mother, and the other members varied between father, stepfather, siblings and different family members. Regarding the education of guardians, the lowest education level was not being able to read or write (parents of one participant) and the highest was having a complete high school (mothers of two participants and father of one). The following categories are explored in the study.

\section{1st theme - I think nobody cares about me}

In this theme, it was evidenced that the way personal relationships are structured (whether between colleagues, boyfriends, parents or guardians) has a great influence on the fact that an adolescent resorted to NSSI. The adolescents described conflicting and helpless relationships, mostly. Aspects of helplessing were referred verbally and also in drawings made by participants.

This started when I was in third grade, I started to being bullied. They started making fun of me. [...] then going to sixth grade I started dating my best friend, the relationship didn't work out. I had many failed relationships (Dafne).

Amanda's Drawing-Story: This is my stepfather and my mother fighting, and me and my brother crying. I have many reasons to cut myself, and this is one of them. (Figure 1)

It is also noted in the narratives that adolescents do not find in their personal network support and understanding when they try to talk about their feelings and about NSSI, which leads them to experience feelings of invalidation, sadness, and loneliness.

l've tried to talk to my parents, but they don't take it too seriously, they don't believe in me very much. I've tried to talk to my friends too, but they say it's nothing (Marina).

Most of the time they say it's drama I don't care so much, but it hurts, because it is not drama. Then this makes me even lower (Julia). 


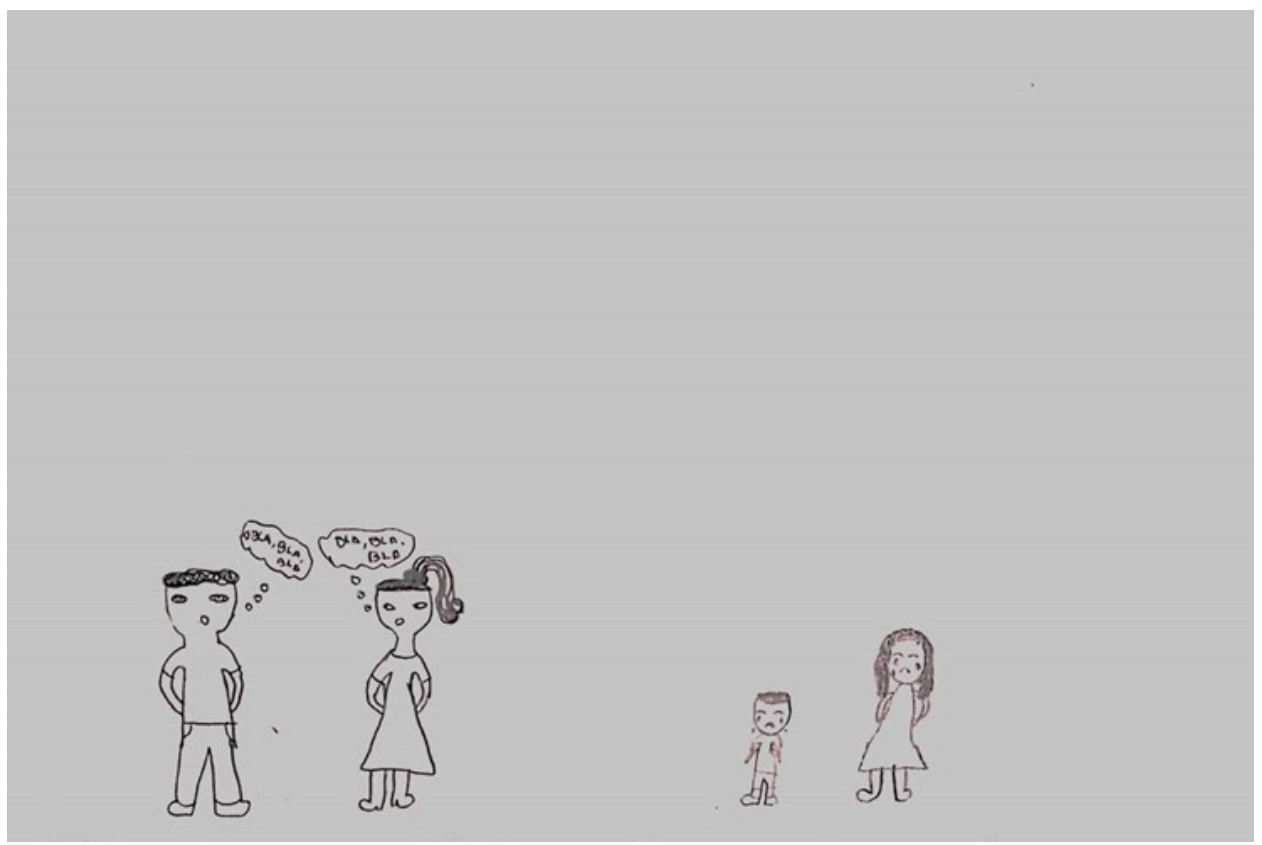

Figure 1 - Amanda's Drawing-Story. City of the state of São Paulo, Brazil, 2019.

I felt alone, with no one, so I cut myself (Nicole).

Also, in this aspect, after experiences of invalidation and helplessness, adolescents do not find room for expression of feelings and are shutted up as a reaction to these experiences.

Then I hold the crying and breathe, because if I drop a tear, I won't be able to stop crying, I'm going to have to come up here, they're going to call my mom, and it's going to be hard to explain to my mom, because I don't feel comfortable talking about these things with her (Marina).

Even though we feel bad on the outside, we always try to smile, show people that we're fine, but it is not easy [...] because if we say we're not, they start asking why and I won't be able to get it off of my chest. They will say that it is nothing (Leticia).

The repercussions seem to be even greater when lack of support comes from parents and family. Many adolescents reported that their parents' reaction to discovering that their daughters were self-injured was aggressive or negligent, causing feelings of guilt and helplessing.

[...] I told my mother that she had to try to understand me, she said that she does not have to try to understand me, I have to try to understand her, because she does everything for me, that I was being a disappointment to her, then she came and slapped on my face (Marina).

I came home and she didn't say anything, then after I took my brother to school, she asked why I was cutting myself and she started cursing at me, started crying, didn't go to work, stayed there with me. [...] then she hit me, grounded me, said I don't need to do anything else for her, because everything I do I complain about (Leticia).

Still in the context of personal relationships, when questioned about the support network, the adolescents reported having a small and fragile network, composed mostly of peers at school. Only one of the participants stated that, in addition to some friends, she had her aunt and the Center for Valorization of Life (Centro de Valorização da Vida).

Researcher: Can you think of some people you feel good about talking to? Dafne: "My friend who lives near my house. She it the only one, I can't open up to my mom, you know (Dafne)?

I don't know, I think nobody cares about me. Then I go to my room, I'm there alone, I cry (Leticia).

It is observed that in this unwelcoming and supportive environment, adolescents use the experience of NSSI. Considering these situations, statements as "only had the blades that helped 
me (Marina)" and "I think nobody cares about me (Leticia)" are recurrent and associated with NSSI as coping and relief of stressors.

\section{$2^{\text {nd }}$ theme - I do not see the colors I used to see before}

This theme addresses adolescence issues scored freely by participants in their statements, which were strongly articulated to the experience of NSSI. Here appears the issue of the passage from childhood to adolescence through the mourning of the loss of childhood and by characteristics of adolescence, such as the search for identity not always supported by the environment.

It's not a very good change... it was all so good, I was so happy, but now at a certain age I started thinking about these things, I started to feel alone. I began to lose hope of everything. But at the same time, it's being good, because I'm becoming a woman (Dafne).

The childhood appears idealized, symbolized by colors. Adolescence, on the other hand, is represented by gray and by speeches of others that charactere it as a phase, as something that passes.

People say it's something that goes away, but it doesn't (Marina)!

My mother even told me these days that I was such a cheerful girl, she didn't even know what was happening to me, imagine me (Dafne).

Sometime we feel worse, sometimes we don't. But I do not see the colors I used to see before (Leticia).

Leticia's Drawing-Story: Mine at the beginning was like this, all happy, all with joy, all right, birds, all cute, my mother and my father, all right. Then there was no more color, there was nothing else. My friends made fun of me at school, so I started cutting myself. My father and mother always cursed at me, it was always me, I was always wrong. And my brother always laughed. (Figure 2)

When referring to self-image, participants bring reports of low self-esteem and self-depreciation.

Now I started going to church, and then when someone doesn't want to talk to me, or just doesn't want to talk, doesn't want to be close, comes this voice saying it's my fault, that l'm bad, that nobody likes me and that I did something wrong (Amanda).



Figure 2 - Leticia's Drawing-Story. City of the state of São Paulo, Brazil, 2019. 


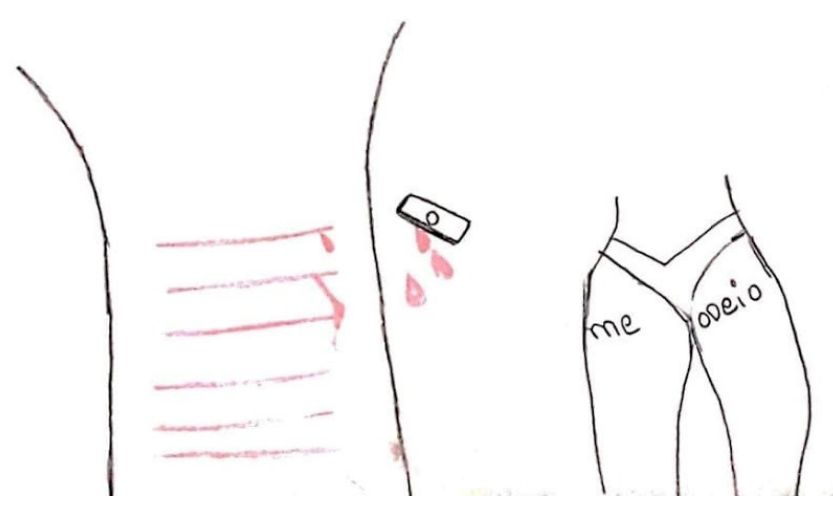

Figure 3 - Julia's Drawing-Story. City of the state of São Paulo, Brazil, 2019.

Julia's Drawing-Story: I did it here, because in the old days I cut myself. And here's my leg, I had written "I hate myself" on my leg here, because I reached to a point where I didn't like myself, because everything was going wrong for me. (Figure 3)

\section{DISCUSSION}

It is noteworthy the fact that all participants in this study were female. Studies have pointed out a greater number of this behavior in girls. ${ }^{19-20}$ However, a recent study developed with a significant sample of adolescents aged approximately 15 years from ten European countries and Israel identified that there was no association between gender and a first NSSI event. ${ }^{21}$ One of the issues raised is that these studies that indicate an association of NSSI with females were conducted with younger adolescents. ${ }^{21}$ Another issue is that there may be gender differences, essentially by cumulative events related to NSSI, one of which is the peer-to-peer relationship, which can have different implications for boys and girls. Such relationships can lead to greater vulnerability to emotional and behavioral problems in girls. ${ }^{21}$

The elements present in adolescents' experiences about NSSI make us look directly at the environment in which they are inserted and their countless possibilities of relationship and to the process of being an adolescent. Should adolescence be seen only as a phase? Do adolescents need less of a supportive environment than children? How can we hold the adolescent suffering, often emanating from the lack of this environment? What is the role of the family and society before NSSI and the healthy development of adolescents?

Adolescents reported experiences in environments perceived by them as hostile and nonsupporting, where they did not find alternatives for stressor relief, facilitating the recurrence of NSSI. The same environment invalidates and strikes when episodes of NSSI are explained, leading to the impossibility of true expression. Winnicott discusses in his work the importance of a facilitating environment for healthy maturation at all stages of life. ${ }^{12}$ For the existence of a facilitating environment it is essential that there is holding, a concept initially described as a set of physical and psychological care given to babies in the period after their birth, highlighting maternal support and reception. ${ }^{12}$ Throughout his work, Winnicott broadens understanding holding beyond maternal care, bringing the notion of care performed in an environment that welcomes subjects physically and psychologically. ${ }^{12}$ 
Thus, the environmental conditions that enable holding are decisive for the establishment of individuals' health, as well as the psychopathologies and the different forms of mental suffering are directly associated with environmental failures or intrusions, such as neglect, violence, traumas that invade the subject. ${ }^{12} \mathrm{~A}$ study developed with adolescents who were victims of violence and in institutional care revealed that affective social support was decisive to break up situations of violence to which they were exposed, essentially coming from the community. Moreover, the emotional support received by institution professionals was pointed out as significant for coping with the situations experienced and adaptation, demonstrating the relevance of holding before stressful experiences lived in adolescence..$^{22}$

Interpersonal relationships, as an indispensable and determining part for the quality of the environment, play a fundamental role in the health experience of these participants. It is observed the importance that these relationships have both in the report of the participants and in winnicott's theory. The importance of the experience lived with the other is pointed out at all times in Winnicott's work. ${ }^{12}$ Winnicott says that it is only through experience and, fundamentally, the experience lived with the other, that the process of maturation takes place. ${ }^{12}$ When talking about dependency relations, it is important to highlight that even the stage of greatest independence is still a relative independence, demonstrating the need for the presence of another human being at all times. ${ }^{12}$

Adults' autonomy, that begin to present itself in adolescence, can only be achieved in fact when there is a social support capable of doing so. Winnicott's work points out how fundamental an environment is to support individuals to separate from it and thus be able to be alone. It is understood that relating is fundamental in psychic maturation throughout life, because even the full expression of autonomy and the ability to be alone depend on the environment and social support. ${ }^{12}$

The importance given to personal relationships and support network is corroborated by literature. English adolescents, in a study that sought to identify strategies for prevention of NSSI, suggested that having a social support capable of listening and welcoming is an important means of preventing NSSI and demonstrating support for people who feel like self-injury. ${ }^{23}$ In this same study, adolescents pointed out that they often feel a desire for more love, attention, time, support and care from their families, who should show more support and understanding about the changes faced in adolescence to prevent NSSI. It was also mentioned that friendships and relationships among peers are protective factors, pointing to the correlation between dysfunctional personal relationships and the occurrence of NSSI. Another study conducted in Belgium and the Netherlands showed that family support offers adolescents the opportunity to face depressive feelings adequately, instead of resorting to NSSI. ${ }^{24}$

Despite the importance revealed by participants, their support network was weak. This data supports a study conducted with families involved in violence against children and adolescents, in which the bonds between families and institutions were weak and based on timely and informative support. Families, especially in situations of vulnerability, were isolated. In this sense, they have difficulty breaking cycles of illness, as well as offering a supportive environment to children and adolescents.

Therefore, it is urgent that nursing, because of its privileged place in health services, in interdisciplinary and intersectoral articulation, build strategies for actions that include family-centered care, comprehensively and through significant and empowering interventions. ${ }^{21,25}$

When the participants talk abour personal relationships and their importance, they indicated bullying as a relevant trigger for NSSI, reinforcing previous findings that demonstrate that there is a positive correlation between being bullied and having self-injurying behaviors. ${ }^{24,26-27}$ Adolescents who are bullied have an increased risk of self-injury. Suffering from this type of violence and the inability to react appropriately to this can cause stress, fear and depression, which, consequently, can be a trigger for self-injurying behaviors as a means of facing such emotions. ${ }^{24}$ 
From a macrosocial perspective, one can think of these issues, understanding them as results of social processes and, especially, those that unfold in schools and families. This aspect increases those involved or responsible in coping with NSSI and facilitating healthy maturation in adolescence, since participants demonstrated great dependence on the environment and adults. This aspect is corroborated by a study in the field, in which misfits in interpersonal events, namely relationships with the family and among peers, presented themselves as risk factors proximal to the first episode of $\mathrm{NSSI}$ in adolescence. ${ }^{23}$ Also in the study cited, the results reinforced the role of cumulative stressor events throughout life, bringing to the fore the relevance of comprehensive monitoring of growth and development of children and adolescents by health teams. ${ }^{23}$

Winnicott observed that one of the paradoxes of adolescence is the oscillation between child dependence and adult independence, going back and forth several times in this development process throughout life cycle. ${ }^{28}$ This paradox leads us to discuss another of the elements brought by participants: the mourning for the end of childhood.

When becoming an adolescent, there is a rupture of the previously established "me as a child" and there is a need for commitment to solve this problem of existence, and to discover the current identity. ${ }^{28}$ With the advent of puberty, physical transformations can, in fact, represent a break in continuity of life, and represent something dislodged from one's person, bringing with it some important changes to the emotional development process. Firstly, adolescence potentiates a power to dominate and destroy that can be daunting. Secondly, it leads them to repeat the anxieties of early stages of development. Moreover, all these changes favor the feeling of unreality, and their struggle, at that moment, is to feel real. ${ }^{28}$

The nature of self-injury seems to be related to the way in which subjects experience and handle the demands of an unhealthy environment. When an adolescent, awkward to express himself/ herself in words, experiences trauma scans in this type of environment, he/she can resort to self-injury as a relief from psychic pain in an attempt to manifest it in the physical body. ${ }^{28}$ What should be the attitude of society, school, family and health professionals in facing NSSI and adolescent psychological distress? This attitude includes understanding, welcoming and being present in the face of paradoxical needs, supporting conflicts and aggression that can naturally emerge in adolescence. It is a delicate task that, as Winnicott points out, is quite different from seeking a cure for the ills of adolescence. ${ }^{28}$

After all, adolescence, despite chronological demarcations, is a relatively recent social construction. It is a dynamic period, crossed by cultural and historical marks, which should not be analyzed only by chronological or biological bias. ${ }^{1}$ It should be understood in itself, and not only as a period of preparation for adulthood. Like any stage of human development, this is also a unique moment, which varies from person to person. Therefore, care and attention should always be based on comprehensiveness. ${ }^{1}$

Finally, it should be noted that the results of this study have some limitations, such as the sample composed only of female adolescents and the fact that these were recruited only through nomination of the school board. The data found point to the need for further studies to address the NSSI coping strategies used by adolescents and the view of family members and professionals who deal directly with the NSSI, as education and health professionals about the phenomenon.

It is noteworthy that nursing plays an articulating role of policies between these sectors, as well as can use care spaces, especially in $\mathrm{PHC}$, such as home visits, welcoming and consultations to enhance healthy environments aiming at the comprehensive development of adolescents. Furthermore, it can collaborate in the construction of technical standards and care flows aimed at the qualified care of adolescents, ${ }^{29}$ as well as in the intersectoral articulation of programs for injury prevention and health promotion. 


\section{CONCLUSION}

From the experiences of adolescents who self-injured, it was observed that this is a multiple phenomenon closely related to the environment, which deserves attention and care in the field of child and adolescent health. The issues present in the process of becoming an adolescent emerged as essential elements for understanding and coping with NSSI.

Due to their multiple characteristics, NSSI coping and prevention policies should include several areas, such as health, education and social assistance. Strengthening the bonds and the family and peer support network should support such policies, in addition to the presence of mental health programs in schools to raise awareness and offer support to adolescents in mental distress.

Bullying was pointed out as one of the important triggers for NSSI, signaling the importance of including the prevention of this violence in interventions with adolescents who self-injured. It is highlighted, again, that habbits of thinking and talking about health in the school environment should be increasingly present and strengthened.

The approximation of NSSI experiences by adolescents who have self-injured themselves points to paths for future interventions, besides contributing to the phenomenon itself, giving voice to the people involved in it. In this regard, it brings interesting subsidies for planning nursing care to a public still neglected in health actions and to an increasingly present problem in health services.

\section{REFERENCES}

1. Ministério da Saúde (BR). Proteger e Cuidar de Adolescentes na Atenção Básica [Internet]. Brasília, DF(BR): Editora do Ministério da Saúde; 2017 [cited 2019 June 8]. Available from: https://bvsms.saude.gov.br/bvs/publicacoes/proteger_cuidar_adolescentes_atencao_basica.pdf

2. Silva MAI, Mello FCM, Mello DF, Ferriani MGC, Sampaio JMC, Oliveira WC. Vulnerability in adolescent health: contemporary issues. Ciênc Saúde Coletiva [Internet]. 2014 [cited 2019 June 05];19(2):619-27. Available from: https://doi.org/10.1590/1413-81232014192.22312012. Portuguese.

3. Word Health Organization. Global status report on violence prevention [Internet]. Geneva(CH): World Health Organization; 2014 [cited 2019 June 09]. Available from: https://www.who.int/ violence_injury_prevention/violence/status_report/2014/en/

4. American Psychiatric Association. Diagnostic and Statistical Manual of Mental Disorders: DSM-5. 5th ed. Washington, DC(US): American Psychiatric Publishing; 2013.

5. Hawton K, Bergen H, Cooper J, Turnbull P, Waters K, Ness J, et al. Suicide following self-harm: findings from the Multicentre Study of self-harm in England, 2000-2012. J Affect Disord [Internet]. 2015 [cited 2019 June 06];175:147-51. Available from: https://doi.org/10.1016/j.jad.2014.12.062

6. Ministério da Saúde (BR). Secretaria de Vigilância em Saúde, Boletim epidemiológico [Internet]. Brasília, DF(BR): Ministério da Saúde; 2017 [cited 2019 June 08]. Available from: http:// portalarquivos.saude.gov.br/images/pdf/2017/setembro/21/2017-025-perfil-epidemiologicodas-tentativas-e-obitos-por-suicidio-no-brasil-e-a-rede-de-atencao-a-saude.pdf

7. Silva AC, Botti NCL. Self-injurious behavior along the vital cycle: integrative literature review. Rev Port Enferm Saúde Mental [Internet]. 2017 [cited 2019 June 06];18:67-76. Available from: https:/doi.org/10.19131/rpesm.0194

8. Silva AC, Botti NCL. Characterization of the profile of participants in a facebook self- mutilation group. Salud Sociedad [Internet]. 2018 [cited 2019 June 06];9(2):160-9 Available from: https:// doi.org/10.22199/S07187475.2018.0002.00003 
9. Silva AC, Botti NCL. An investigation on self-mutilation in a group of the social network Facebook. SMAD Rev Eletr Saúde Mental Álcool Drog [Internet]. 2019 [cited 2019 Aug 20];14(4):203-10. Available from: https:/doi.org/10.11606/issn.1806-6976.smad.2018.000355

10. Costa JS, Silva AC, Vedana KGG. Posts on non-suicidal self-injury on the internet. Adolesc Saude [Internet]. 2019 [cited 2019 Aug 08];16(1):7-12. Available from: http://www.adolescenciaesaude. com/detalhe_artigo.asp?id=766\&idioma=english\#

11. Fonseca PHN, Silva AC, Araujo LMC, Botti NCL. Non-suicidal self-injury intent among adolescentes. Arq Bras Psicol. [Internet]. 2018 [cited 2019 Aug 08];70(3):246-58. Available from: http://pepsic. bvsalud.org/pdf/arbp/v70n3/17.pdf

12. Winnicott DW. O ambiente e os processos de maturação: estudos sobre a teoria do desenvolvimento emocional. Porto Alegre, RS(BR): Artmed; 1983.

13. Flick U. An introduction to qualitative research. 5th ed. Thousand Oaks, CA(US): Sage; 2014.

14. Ministério da Saúde (BR). Estado de São Paulo, Município de São Carlos, Unidade de Saúde USF Água Vermelha, Relatório de cadastro individual. Brasília, DF(BR): Ministério da Saúde; 2018.

15. Winnicott DW. Consultas terapêuticas em psiquitria infantil. Rio de Janeiro, RJ(BR): Imago; 1971.

16. Aiello-Vaisberg TMJ. Investigação de Representações Sociais. In: Trinca W, ed. Formas de investigação clínica em psicologia: procedimento de desenhos-estorias - procedimento de desenhos de famílias com estórias. São Paulo, SP(BR): Vetor; 1997. p. 255-88.

17. Hennink MM, Kaiser BN, Marconi VC. Code saturation versus meaning saturation: how many interviews are enough? Qual Health Res [Internet]. 2017 [cited 2019 Sept 11];27(4):591-608. Available from: https://doi.org/10.1177/1049732316665344

18. Clarke $\mathrm{V}$, Braun $\mathrm{V}$. Teaching thematic analysis: overcoming challenges and developing strategies for effective learning. Psychologist [Internet]. 2013 [cited 2019 Sept 11];26(2):120-3. Available from: https://www.researchgate.net/publication/269928387_teaching_thematic_analysis_overcoming_ challenges_and_developing_strategies_for_effective_learning

19. Andrew T, Martin G, Hasking P, Page A. Predictors of onset for non-suicidal self-injury within a school-based sample of adolescents. Prev Sci [Internet]. 2014 [cited 2019 Sept 11];5(6):850-9. Available from: https://doi.org/10.1007/s11121-013-0412-8

20. Heerde JA, Toumbourou JW, Hemphill SA, HerrenkohI TI, Patton GC, Catalano RF. Incidence and course of adolescent deliberate self-harm in Victoria, Australia, and Washington State. J Adolesc Health [Internet]. 2015 [cited 2019 Oct 05];57(5):537-44. Available from:https://doi. org/10.1016/j.jadohealth.2015.07.017

21. Kaess M, Eppelmann L, Brunner R, Parzer P, Resch F, Carli V, et al. Life events predicting the first onset of adolescent direct self-injurious behavior - a prospective multicenter study. J Adolesc Health [Internet]. 2020 [cited 2019 Nov 02];66(2):195-201. Available from: https://doi. org/10.1016/j.jadohealth.2019.08.018

22. Carlos DM, Ferriani MGC, Esteves MR, Silva LMP, Scatena L. Social support from the perspective of adolescent victims of domestic violence. Rev Esc Enferm USP [Internet]. 2014 [cited 2019 Sept 10];48(4):610-7. Available from: https://doi.org/10.1590/S0080-623420140000400006

23. Fortune S, Sinclair J, Hawton K. Adolescents' views on preventing self-harm. A large community study. Soc Psychiatry Psychiatr Epidemiol [Internet]. 2008 [cited 2019 Sept 11];43(2):96-104. Available from: https://doi.org/10.1007/s00127-007-0273-1 
24. Claes L, Luyckx K, Baetens I, Van de Ven M, Witteman C. Bullying and victimization, depressive mood, and non-suicidal self-injury in adolescents: the moderating role of parental support. $J$ Child Fam Stud [Internet]. 2015 [cited 2019 Sept 12];24(11):3363-71. Available from: https://doi. org/10.1007/s10826-015-0138-2

25. Carlos DM, Silva LMP, Beserra MA, Aragão AS, Gregory A, Ferriani MDGC. Social support network of family members of abused children and adolescents: Perspectives and possibilities. J Clin Nurs [Internet]. 2019 [cited 2019 Sept 12];28(5-6):814-27. Available from: https://doi. org/10.1111/jocn.14665

26. Klomek AB, Snir A, Apter A, Carli V, Wasserman C, Hadlaczky G, et al. Association between victimization by bullying and direct self injurious behavior among adolescence in Europe: a tencountry study. Eur Child Adolesc Psychiatry [Internet]. 2016 Nov [cited 2019 Set 12];25(11):118393. Available from: https://doi.org/10.1007/s00787-016-0840-7

27. Lereya ST, Copeland WE, Costello EJ, Wolke D. Adult mental health consequences of peer bullying and maltreatment in childhood: two cohorts in two countries. Lancet Psychiatry [Internet]. 2015 [cited 2019 Sept 12];2(6):524-31. Available from: https://doi.org/10.1016/S2215-0366(15)00165-0

28. Winnicott DW. Adolescência: transpondo a zona das calmarias. In: Winnicott DW. A família e o desenvolvimento individual. 4th ed. São Paulo, SP(BR): WMF Martins Fontes; 2011. p. 115-28.

29. Gonçalves CFG, Silva LMP, Pitangui ACR, Silva CC, Santana MV. Network action for the care of adolescente victims of violence: challenges and possibilities. Texto Contexto Enferm [Internet]. 2015 [cited 2019 Sept 11];24(4):976-83. Available from: https://doi.org/10.1590/01040707201500004580014 


\section{NOTES}

\section{CONTRIBUTION OF AUTHORITY}

Study design: Costa LCR, Carlos DM.

Data collect: Costa LCR.

Data analysis and interpretation: Costa LCR, Carlos DM.

Discussion of the results: Costa LCR, Gabriel IM, Carlos DM.

Writing and / or critical review of content: Costa LCR, Oliveira WA, Hortense P, Dicastillo OL, Carlos DM. Review and final approval of the final version: Costa LCR, Gabriel IM, Oliveira WA, Hortense P, Dicastillo OL, Carlos DM.

\section{FUNDING INFORMATION}

It was funded by the São Paulo State Research Support Foundation (Fundação de Amparo à Pesquisa do Estado de São Paulo), Process 2019/09333-9. Coordenação de Aperfeiçoamento de Pessoal de Nível Superior - Brasil (CAPES) - Finance Code 001.

\section{APPROVAL OF ETHICS COMMITTEE IN RESEARCH}

It was approved by the Research Ethics Committee of Universidade Federal de São Carlos, Opinion 3.526.677/2019 and CAAE (Certificado de Apresentação para Apreciação Ética - Certificate of Presentation for Ethical Consideration) 17176219.6.0000.5504.

\section{CONFLICT OF INTEREST}

There is no conflict of interest.

\section{EDITORS}

Associated Editors: Selma Regina de Andrade, Gisele Cristina Manfrini, Laura Cavalcanti de Farias Brehmer, Ana Izabel Jatobá de Souza.

Editor-in-chief: Roberta Costa.

\section{HISTORICAL}

Received: February 09, 2020.

Approved: June 04, 2020.

\section{CORRESPONDING AUTHOR}

Diene Monique Carlos diene_enf@hotmail.com 